Бугайчук Костянтин Леонідович, кандидат юридичних наук, доцент, провідний науковий співробітник науково-дослідної лабораторії 3 проблем профілактики правопорушень та взаємодії 3 населенням, Харківський національний університет внутрішніх справ, м. Харків, e-mail: klbugaychuk@gmail.com

\title{
МОБІЛЬНЕ НАВЧАННЯ: СУТНІСТЬ І МОДЕЛІ ВПРОВАДЖЕННЯ В НАВЧАЛЬНИЙ ПРОЦЕС ВИЩИХ НАВЧАЛЬНИХ ЗАКЛАДІВ МВС УКРАЇНИ
}

\begin{abstract}
Анотація
Сучасні тенденції створення і розширення функціональності портативних електронних пристроїв змушують світову спільноту замислюватися про їх використання з освітньою метою. Останніми роками вчені все частіше говорять про виникнення навчання за допомогою мобільних пристроїв або мобільне навчання. Автором визначена сутність мобільного навчання, його співвідношення 3 дистанційним й електронним навчанням, а також окреслені його переваги і недоліки. На підставі особливостей мобільних пристроїв сформульовано правила розробки інформаційних ресурсів для мобільного навчання. Запропоновано моделі впровадження мобільного навчання в навчальний процес вищих навчальних закладів МВС України.
\end{abstract}

Ключові слова: дистанційне навчання, мобільне навчання, МВС України.

Постановка проблеми. Розвиток дистанційного навчання обумовлений значними змінами на ринку праці, зростанням вимог до персоналу, упровадженням інформаційних технологій у навчальний процес і повсякденну діяльність фахівців. Застосування таких технологій, зазвичай, вимагає наявності в курсантів і слухачів комп’ютера 3 доступом до мережі Інтернет. Інколи цю можливість мають далеко не всі. Поряд із цим практично кожна особа має мобільний телефон, ноутбук, «електронний рідер» або MP3 плеєр, які використовує в основному для спілкування i розваг. В останні два роки стрімкого розвитку набувають теоретичні і практичні дослідження щодо використання мобільних пристроїв у навчальному процесі.

Ця тенденція набула актуальності поряд із початком «ери смартфонів і планшетів», адже саме ці пристрої символізують собою сучасне інформаційне 
суспільство. Так, за даними компанії GfK Ukraine за 2011 рік український ринок смартфонів у кількісних показниках зріс на $68 \%$. Можна також простежити тенденцію до збільшення діагоналі екрану «розумного пристрою»: частка смартфонів, розмір екрана яких знаходиться в діапазоні трьох дюймів, зросла з $74 \%$ до $81 \%$, і від 0 до $13 \%$ зросла частка 4-дюймових смартфонів [1]. Український ринок планшетів також відзначається динамічністю. Прогнози щодо продажів планшетів в Україні у 2012 році становлять близько 150 тисяч. Аналітики пов’язують масове поширення планшетних ПК із збільшенням списку завдань, які можна розв'язати за їх допомогою: пошук інформації в мережі Інтернет, спілкування в соціальних мережах, прослуховування музики, читання книг тощо [2].

Кожен 3 операторів мобільного зв’язку пропонує своїм клієнтам багато можливостей щодо підключення до мережі Інтернет, у тому числі й швидкісного. Випуск фірмою Apple планшетів iPad зумовив появу за кордоном цілого практичного напряму щодо їх застосування в навчальному процесі початкової, середньої та вищої шкіл, а також спричинив велику кількість розробок навчальних додатків до цих пристроїв [3].

Зазвичай, система освіти України не може стояти осторонь таких тенденцій. Можливості мобільних пристроїв, безумовно, потрібно використати в навчальному процесі всіх категорій осіб, адже вони органічно поєднуються 3 традиційними формами навчання, розширюють можливості доступу до навчальної інформації, сприяють входженню України в загальний інформаційний простір.

Аналіз останніх публікацій. На теренах країн СНД, зокрема України, проблеми мобільного навчання досліджували І. М. Голіцина [4], Т. А. Калуга [5], В. А. Куклєв [6], О. О. Семеріков [7], О. Ю. Тихомірова [8] та інші. Проте, на нашу думку, існує потреба розглянути деякі практичні аспекти цього виду навчання, які можливо використовувати в навчальному процесі вищої школи системи МВС України.

Метою публікації $€$ дослідження сутності мобільного навчання, його дидактичних можливостей, видів організації і напрямів застосування в навчальному процесі вищих навчальних закладів системи МВС.

Викладення основного матеріалу. Питання використання мобільних пристроїв у навчальному процесі виникло ще у 20 сторіччі. Відправним пунктом чого 
стали роботи Алана Кея, який запропонував концепцію пристрою Dynabook, що поєднував у собі дисплей, на якому можна було роботи записи, ємку батарею, а також завдяки встановленому програмному забезпеченню надавав можливості доступу до електронних навчальних ресурсів. Цей пристрій став прототипом перших ноутбуків $\mathrm{i}$ планшетів.

Розвиток мобільних технологій зумовлює багатофункціональність портативних мобільних пристроїв. Мобільні телефони, планшети, електронні «рідери» тепер можуть працювати як телефони, калькулятори, навігатори, точки доступу до мережі Інтернет. Вони мають функції відтворення музики й аудіокниг, показу відео, запуску ігор і т. д. 3 розвитком мобільних технологій зросла потреба швидкого доступу до інформації, адже зросла мобільність самого населення. Тому особливої актуальності набуває пошук нових підходів до організації навчального процесу i створення навчальних матеріалів, які б враховували можливості мобільних технологій. Саме ці технології і зумовили виникнення поняття «мобільне навчання» або «m-learning» навчання за допомогою мобільних пристроїв, навчання в будь-який час і в будь-якому місці. Як же вчені визначають сутність мобільного навчання?

Мобільне навчання - навчання в умовах, коли учень має мобільний доступ до освітніх ресурсів, може взаємодіяти з викладачем та іншими учнями [9].

Термін m-learning зводиться до використання мобільних і кишенькових ITпристроїв, таких як персональний цифровий помічник (PDA), мобільні телефони, ноутбуки і планшетні ПК, у викладанні й навчанні [10].

Мобільне навчання тісно пов'язане з електронним і дистанційним навчанням, особливістю його $є$ використання мобільних пристроїв. Навчання проходить незалежно від місця знаходження і відбувається 3 використанням портативних технологій. Іншими словами, мобільне навчання зменшує обмеження із здобуття освіти щодо місцезнаходження за допомогою портативних пристроїв [11].

Використання портативних обчислювальних пристроїв (таких як ноутбуки, планшетні ПК, КПК і смартфони) разом із бездротовими мережами дозволяє говорити про мобільне навчання. Завдяки йому виникає можливість викладати і навчатися в будь-якому місці за межами традиційної аудиторії [12]. Це будь-яка діяльність, яка дозволяє людям бути більш продуктивними шляхом взаємодії, або створення 
інформації, за допомогою цифрових портативних пристроїв, які можуть зберігатися в кишені або сумочці [13].

Апаратними пристроями для мобільного навчання можна назвати:

- телефони: звичайні мобільні телефони, смартфони, комунікатори;

- портативні комп’ютери: ноутбуки, нетбуки, Інтернет планшети;

- пристрої зберігання і відтворення інформації: електронні «рідери» (Pocket Book, Amazom Kindle), MP3/MP4 плеєри.

Відповідний науковий інтерес викликає співвідношення термінів «мобільне навчання», «дистанційне навчання», «електронне навчання (e-Learning)». Спочатку електронне навчання розумілося як навчання за допомогою комп'ютерів. E-Learning це всі форми електронної підтримки для навчання - викладання, які носять процедурний характер і спрямовані на побудову знань з урахуванням індивідуального досвіду, практики i знань учнів. Свропейська комісія визначає e-learning як «використання нових інформаційних технологій, технологій мультимедія і Інтернет (ICT) для підвищення якості навчання за рахунок поліпшення доступу до ресурсів i сервісів, а також віддаленого обміну знаннями і спільної роботи» [14].

Завдяки розвитку комп`ютерної й Інтернет технологій e-learning розуміється по-різному. Так, скорочення СВТ (комп'ютерне навчання), IBT (Internet (Intranet)Based навчання) або WBT (Web-Based навчання) дуже часто використовуються як синоніми e-learning.

Дистанційне навчання визначають як форму навчання, що реалізується в умовах віддаленості слухача i науково-педагогічного працівника на основі використання сучасних педагогічних й інформаційно-комунікаційних технологій. Така форма навчання дає свободу вибору місця, часу та темпу навчання. Інколи дистанційне навчання й e-learning ототожнюють.

Отже, мобільне навчання співвідноситься з поняттями дистанційне навчання й електронне навчання так. Якщо останні два поняття розуміти як окремі, то мобільне навчання має спільні риси з електронним навчанням у питаннях використання «мобільних пристроїв» і бездротових мереж, а 3 дистанційним навчанням поєднується тим, що воно здійснюється у будь-який час, будь-де, причому в навчальному процесі обов' язково має місце взаємодія викладача і слухача. Якщо ці поняття ототожнювати, то мобільне навчання буде одним з підвидів дистанційного навчання або e-leaning. 
На підставі цього можна виділити типові ознаки мобільного навчання:

- використання мобільних пристроїв (мобільні телефони, ноутбуки, КПК, планшети, електронні читачі «рідери» тощо);

- взаємодія учасників навчального процесу забезпечується і підтримується за допомогою бездротових мереж;

- навчання здійснюється незалежно від часу i місця знаходження його учасників;

- під час здійснення мобільного навчання створюється мобільне інформаційно-освітнє середовище;

- мобільне навчання пов’язане з електронним і дистанційним навчанням.

Безперечно, що в разі впровадження мобільного навчання в навчальний процес вищого навчального закладу нагальним стає питання щодо його всебічного забезпечення. Аналіз стратегічних питань впровадження мобільного навчання в діяльність навчальних закладів і комерційних структур $[15,16]$ дає змогу виділити такі види необхідного забезпечення:

- організаційно-правове забезпечення (нормативно-правові акти, що регламентують впровадження мобільного навчання в навчальний процес ВНЗ, окремі організаційні структури, що реалізують стратегію впровадження мобільного навчання);

- методичне забезпечення (теоретичні i практичні рекомендації щодо розробки мобільних інформаційних ресурсів і використання мобільних пристроїв у навчальному процесі, змістовне, дидактичне та методичне наповнення інформаційних ресурсів, створених для мобільного навчання, методичні рекомендації щодо розрахунку навчального навантаження для розробників контенту тощо);

- інформаційне забезпечення (інформаційні ресурси, що використовуються в навчальному процесі, 3 використанням мобільних пристроїв: дистанційні курси, електронні підручники, окремі інформаційні ресурси та інші бази і банки даних, у тому числі й ті, що розміщені в мережі Інтернет);

- кадрове забезпечення (управлінський, науково-педагогічний, інженерний та допоміжний склади, що реалізують стратегію мобільного навчання); 
- $\quad$ технічне забезпечення (апаратне, комунікаційне та програмне забезпечення мобільного навчання: мобільні пристрої, бездротові мережі, окреме програмне забезпечення, система управління мобільним навчанням (LMS) тощо);

- фінансове забезпечення.

Західні вчені виділяють такі моделі мобільного навчання.

1. Web-модель. Користувачі мають доступ до навчальних ресурсів iз мобільних пристроїв за допомогою бездротових мереж зв'язку й Інтернету. У результаті мобільний пристрій починає функціонувати як персональний комп'ютер, за допомогою якого, окрім веб-сторінок, також можна отримати доступ до електронної пошти, поспілкуватися в чаті тощо.

2. Арр-модель. Виникнення цієї моделі пов'язано 3 «ерою смартфонів», які мають операційну систему і для яких створюються різноманітні додатки (програмне забезпечення для роботи на мобільному телефоні). Додаток може надати користувачеві будь-яку функціональність або можливості: словники, конвертори величин, сканери QR кодів, GPS тощо.

3. Стільникова модель. Стільникова модель дозволяє використовувати телефонні можливості мобільного пристрою, оскільки кожен телефон має в основі передавання голосу i даних. До таких прикладів можна віднести sms-вікторини, голосові консультації тощо [17].

Важливим питанням мобільного навчання є розробка інформаційних ресурсів, яка має свої особливості. Розробники мають враховувати такі фактори: обмеження часу для навчання, обмеження мобільних пристроїв, обмеження мереж мобільного зв’ язку. Спираючись на вищезазначене, окреслимо деякі практичні поради:

- $\quad$ мобільні пристрої мають обмежений розмір екрана, менші клавіатури та обмежені пропускною здатністю для мультимедійних файлів. Важливо, щоб дизайн мобільного контенту враховував ці особливості, а не просто повторював уже існуючу структуру звичайного контенту. Наприклад, доречною є розробка мобільних версій навчальних сайтів, які забезпечують швидкий доступ до них, а також мають оптимальні параметри для роботи з інформацією за допомогою мобільних пристроїв;

- розробляючи мультимедія, потрібно враховувати формати фото-, аудіота відеофайлів, що підтримуються мобільними пристроями. Доречним є створення цих матеріалів у форматах: PNG, GIFT, 3GP, MP3, MP4; 
- $\quad$ ефективною $є$ розробка навчальних елементів, розрахованих на 10-15 хвилин навчальної роботи. Приклад таких коротких модулів - ресурси академії Хана (Khan Academy), тривалість яких підпадає під ці рамки. Це також пов’язано з тим, що найчастіше мобільний пристрій використовується у перервах між основними видами діяльності, тому і навчання повинно охоплювати короткі проміжки часу;

- під час розробки навчальних матеріалів треба враховувати анатомічні особливості людини (товсті чи худі пальці), якість зору. Мобільні матеріали повинні мати область для роботи пальцями (для сенсорних пристроїв), а також чіткий крупний шрифт і зрозумілі зображення;

- не треба перевантажувати навчальні матеріали мультимедія, адже це впливає на швидкість завантаження інформації, а деякі пристрої взагалі не розраховані на роботу з «важкими» файлами;

- $\quad$ для ефективності мобільного навчання треба постійно слідкувати за оновленням матеріалів, адже аудиторія постійно знаходиться на зв’язку, і в будь-яку мить може скористатися наявним контентом, тому треба його підтримувати в актуальному стані.

Враховуючи вищезазначене, вважаємо, що в навчальному процесі вищих навчальних закладах системи МВС доцільним є застосування двох підходів (моделей) мобільного навчання: on-line й off-line. Слід зазначити, що ці моделі можуть застосовуватися як в рамках дистанційного, так і традиційного (очного, заочного) навчання.

On-line (мережеве) мобільне навчання. Воно має за основу принцип використання мобільних пристроїв, які мають доступ до мережі Інтернет.

У межах on-line виду доступ курсантам і слухачам до навчального контенту здійснюється через спеціальний сайт навчального закладу, також інформація може бути розташована на окремих сайтах у мережі Інтернет. Доцільною $є$ розробка мобільних версій сайтів навчальних закладів МВС України, які якнайкраще пристосовані до потреб мобільних пристроїв. У процесі роботи курсанти і слухачі матимуть можливість знайомитися 3 навчальною інформацією, спілкуватися у форумах, проходити тестування, коментувати навчальний матеріал, розміщувати власний матеріал. 
Розвиваючи цю технологію, потрібно активно використовувати можливості соціальних сервісів. Так, у багатьох мобільних пристроях уже вбудовані клієнти сервісів twitter, Facebook, uTalk. Виробники телефонів, КПК або планшетів інколи встановлюють в них цілу систему сервісів, найчастіше це Google або Yandex (у випадку країн СНД). Крім того, планшети і смартфони дозволяють встановлювати клієнти інших соціальних сервісів. У разі використання пристроєм операційної системи Android він уже оснащений встановленим соціальними сервісами Google: Gmail, Google groups, Google docs, Google +, Blogger тощо. Соціальні сервіси дозволяють створювати, поширювати та отримувати навчальну інформацію. 3 їх допомогою можна коментувати інформацію учасників навчального процесу, спільно створювати документи, робити масове розсилання повідомлень.

Взаємодія у мережевій технології між курсантами, слухачами та викладачем може бути синхронною й асинхронною. Доступ до мережі Інтернет забезпечується за допомогою Wi-Fi або GSM мереж.

Off-line (автономне) мобільне навчання. Полягає у використанні можливостей платформи мобільного телефону для відтворення інформаційного контенту різного формату (текст, зображення, відео, фото, звук). Для цього використовуються програвачі відео і звукових файлів, пакети програм Microsoft Office, переглядачі файлів *pdf *txt *fb2 тощо. Автономне навчання також передбачає використання різноманітних програм: словників, калькуляторів, перекладачів, яким не потрібний Інтернет для коректної роботи. У межах автономного навчання для мобільних телефонів навчальним закладом можуть створюватися спеціально адаптовані електронні посібники, програми тестування тощо, проте, слід зазначити, що розробка таких додатків дуже трудомісткий процес.

Отже, за наявності в пам'яті мобільного телефону файлів, що містять навчальну інформацію, можна переглядати їх версії, адаптовані спеціально для екрана телефону, зі зручними смугами прокрутки, відповідним шрифтом і адаптованим інтерфейсом.

У разі вибору цієї моделі у викладача має мати набір навчальних матеріалів, розроблених для автономної роботи: текстові файли, відеоматеріали й аудіофайли (навчальні фільми, підкасти, аудіопідручники, озвучені презентації тощо).

На відміну від попередньої моделі, взаємодія викладача і курсанта або слухача відбувається асинхронно і тільки у разі виникнення можливості зв’язку (очна сесія, 
тимчасове користування Інтернетом тощо) або відбувається засобами стільникового зв’язку (голосові розмови, SMS). Проте в цьому випадку навчальна інформація завжди знаходиться в курсанта або слухача, незважаючи на наявність Інтернету.

Вважаємо за доцільне зупинитися на новому методі відтворення інформації для мобільного навчання - QR кодах. QR код (двовимірний або матричний код) - це наступне після штрих-коду покоління технології кодування інформації. 2D коди здатні нести в собі значно більший обсяг інформації й ефективніше розпізнаватися камерою мобільного телефону, ніж звичайний штрих-код. Щоб зчитати QR код, необхідно встановити на мобільний телефон спеціальну програму і запустити ї. Після того, як програма активує камеру, навести іï на зображення коду і виконувати дії згідно з підказками програми.

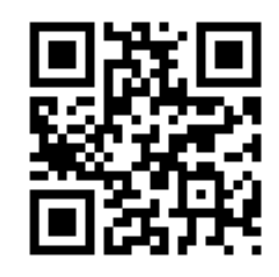

Puс. 1. QR код, який містить посилання на блог автора статті

Якщо у користувача є Android смартфон, то він можете встановити будь-яку програму зчитування цих кодів з Інтернет-ресурсу Android market, там же можна знайти q програми генерації QR кодів. У випадку використання Інтернет-браузера Chrome можна встановити додаток «Instant Goo.gl URL Shortener + QR Code», за допомогою якого можливо згенерувати QR код i відправити його курсантам, слухачам, колегам електронною поштою, SMS або додати до наукової публікації.

Серед основних прикладів використання цих кодів у повсякденному житті $\epsilon$ кодування Інтернет-посилань, які можна отримати внаслідок декодування коду i моментально потрапити на відповідну сторінку в Інтернеті без введення довгих Інтернет-адрес. Також поширене кодування короткого інформативного тексту, наприклад, контактів з візитки або невеликих повідомлень. Існує безліч on-line інструментів для генерації кодів. Так, доцільно порадити ресурс http://qr.aaa-nan.info. На цьому ж сайті є мобільна версія продукту http://qr.aaa-nan.info/mobile.php. Ще один відомий ресурс розташований за адресою http://qrcode.kaywa.com.

Основні напрями використання QR кодів у навчальному процесі: 
- додаток до тексу в публікаціях. QR код міститься прямо в тексті і слухач, зчитавши його за допомогою мобільного пристрою, може потрапити на Інтернетресурс, який мітить додаткову інформацію до тексту (відео, фото). Під час викладання юридичних дисциплін це можуть бути посилання на статті законодавства, відео про практичне застосування заходів примусу тощо;

- додаток до навчального об’єкта. Під час вивчення будь-яких макетів розмістіть QR код на фрагменті об'єкта, щоб пояснити за допомогою додаткових ресурсів його особливості. Так, QR коди можна розміщувати на частинах машин, елементах механізмів, картинах, анатомічних об'єктах. Для вивчення юридичних дисциплін ці коди можна використовувати на заняттях зі спецтехніки, криміналістики (зразки куль, замків, слідів, анатомія людини тощо);

- курсанти і слухачі можуть створити власне портфоліо, зашифрувавши його за допомогою QR коду.

\section{Переваги мобільного навчання:}

- зручність і гнучкість. Навчальний процес 3 використанням мобільних пристроїв може здійснюватися незалежно від часу і місця знаходження слухача i викладача;

- мобільне навчання дозволяє використовувати «мертвий час». Це, як правило, час у дорозі, у черзі, в очікуванні на зустрічі тощо;

- мобільні пристрої можна використовувати для швидкого створення i подальшого передавання інформації (фото, відео, диктофон, SMS, MMS);

- невеликий екран (як правило) мінімізує кількість інформації, яка може міститися у навчальному об'єкті (пам'ятайте принципи дизайну мобільного контенту), тому можна уникнути когнітивного перевантаження;

- подолання технологічного бар'єру. Використання відповідних пристроїв дає слухачеві додатковий досвід, а також спонукає його до пошуку нових способів використання власного пристрою, у тому числі для задоволення навчальних потреб;

- персоналізація навчання. Уся інформація відображається тільки для користувача пристрою, до то ж мобільний пристрій налаштований відповідно до індивідуальних потреб слухача; 
- мобільне навчання підходить для різних стилів навчання: читання, перегляд фото та відео, слухання підкастів, участь у дискусіях (форум або SMS), пошук інформації в Інтернеті, проходження тестів, участь у вікторинах тощо.

\section{Недоліки (проблеми) мобільного навчання:}

- дефіцит якісного повнофункціонального освітнього контенту для мобільних пристроїв і засобів його розробки;

- низька «технічна» підготовка викладачів у галузі створення мобільного контенту;

мобільного навчання;

- обмежений термін дії батареї мобільного пристрою;

- відсутність, подекуди, якісного Інтернет покриття. До речі, на Україні тільки 1 оператор має ліцензію на зв'язок 3G, інші мережі, які працюють у стандарті CDMA 2000, покривають невелику територію (як правило, великі міста). Крім того, у навчальних закладах практично не підтримується розвиток бездротової мережі;

- невеликий розмір екранів мобільних пристроїв. Хоча на теперішній час із розповсюдженням планшетів, смартфонів та нетбуків цей недолік частково усувається;

- велика кількість стандартів, розмірів екрану та операційних систем;

- наявність «цінового бар'єру» для користувачів. Окрім вартості самого пристрою, треба згадати про вартість мобільного Інтернету. Українські оператори мобільного зв’язку пропонують Інтернет пакети вартістю від 30 гривень на місяць, що також слід додавати до вартості навчання;

- наявність «цінового бар'єру» для навчальних закладів. На жаль, рівень фінансування навчальних закладів не дозволяє будувати бездротові мережі належної якості. Оптимальним кроком для впровадження мобільного навчання $\epsilon$ централізоване придбання мобільних пристроїв у виробника, але низький рівень фінансування спонукає до використання студентами і слухачами в навчальному процесі своїх власних пристроїв.

Проведене нами дослідження дозволяє сформулювати відповідні висновки й узагальнення. 
Мобільне навчання все більше пов'язує навчання 3 життям і роботою, причому цей вид діяльності перестає бути пов’ язаним виключно зі школою, університетом або іншим стаціонарним навчальним закладом.

У науковій літературі місце мобільного навчання («m-learning») у загальній системі освіти визначається 3 двох основних позицій. Відповідно до першої воно є підвидом дистанційного навчання, а згідно з другою - $є$ окремим видом навчання, хоча і має спільні риси з дистанційним й електронним навчанням.

Мобільне навчання реалізує принципи відкритої освіти: гнучкість, модульність, незалежність від місця і часу, використання сучасних інформаційно-комунікаційних технологій. У мобільному навчанні на перше місце виходять такі дидактичні принципи як мультимедійність, інтерактивність, доступність.

Отже, визначення «мобільне» характеризує насамперед дві основні складові педагогічного процесу - доступ до навчальної інформації i форми реалізації навчальної інтеракції. Курсанти і слухачі нині можуть мати миттєвий доступ до навчальних матеріалів і програм, навчальних ресурсів, виконувати завдання, спілкуватися з викладачем в будь-який час і в будь-якому місці. Мобільне навчання здійснюється у специфічному інформаційно-освітньому середовищі, дидактичними властивостями якого $є$ висока швидкість створення, обробки й передавання інформації, двосторонній характер комунікацій, можливість роботи з гіпертекстом i мультимедія, відкритий доступ до інформаційних ресурсів.

У вищих навчальних закладах системи МВС можливим є застосування двох моделей мобільного навчання: on-line i off-line. Слід зазначити, що ці моделі можуть застосовуватися як у рамках дистанційного, так і традиційного (очного, заочного) навчального процесу.

Запровадження мобільного навчання потребує від вищого навчального закладу створення системи його забезпечення: правового, інформаційного, кадрового, методичного, фінансового.

Перспективними напрямами подальших досліджень $є$ питання стратегії впровадження мобільного навчання в навчальний процес вищих навчальних закладів, програмні засоби створення навчальних матеріалів для мобільного навчання, педагогічні і психологічні основи мобільного навчання. 


\section{Список використаних джерел}

1. Рынок смартфонов в Украине вырос почти на 70\% [Електронний ресурс]. - Режим доступу : http://rus.newsru.ua/finance/29nov2011/smart.html.

2. Планшеты вошли в моду [Електронний ресурс]. - Режим доступу : http://markets.eizvestia.com/full/planshety-voshli-v-modu.

3. From e-Learning to iPad: How to Adjust the User Interface [Електронний pecypc]. - Режим доступу : http://www.learningsolutionsmag.com/articles/606/from-elearning-to-ipad-how-to-adjust-the-user-interface.

4. Голищьына И. H. Мобильное обучение как новая технология в образовании [Електронний ресурс] / И. Н. Голицына. - Режим доступу : http://ifets.ieee.org/russian/depository/v14_i1/html/1.htm.

5. Калуга T. А. Мобильное обучение в дистанционном образовании [Електронний ресурс] / Т. А. Калуга // Вісник ЛНУ імені Тараса Шевченка. - 2011. № 12 (223), Ч. I. - С. 113-123. - Режим доступу до журн. : http://www.nbuv.gov.ua/portal/Soc_Gum/Vlush/Ped/2011_12_1/15.pdf.

6. Куклев В. А. Сущностные характеристики мобильного обучения как педагогической инновации [Електронний ресурс] / В. А. Куклев // Мир науки, культуры, образования. - 2008. - № 5(12). - С. 204-207. Режим доступу до журн. : http://www.iwep.ru:88/journal/12/pages\%20204-207.pdf.

7. Семеріков С. О. Фундаменталізація навчання інформатичних дисциплін у вищій школі : монографія / С. О. Семеріков; науковий редактор академік АПН України, д. пед. н., проф. М. І. Жалдак. - К. : НПУ ім. М. П. Драгоманова, 2009. $340 \mathrm{c}$.

8. Мобильное обучение - второе рождение, но те же трудности [Електронний pecypc]. http://elearningtime.blogspot.com/2011/01/blog-post_17.html.

9. Мобильное обучение [Електронний ресурс]. - Режим доступу : http://goo.gl/7UdXI.

10. What is Mobile Learning? [Електронний pecypc]. - Режим доступу : http://archive.excellencegateway.org.uk/page.aspx?o=135556.

11. Мобільне навчання [Електронний ресурс]. - Режим доступу : http://goo.gl/Yb9Pz. 
12. M-Learning and Mobility [Електронний ресурс]. - Режим доступу : http://www.educause.edu/ELI/LearningTechnologies/MLearningandMobility/12397?page_i $\mathrm{d}=12397 \&$ bhcp $=1$.

13. What is m-learning? [Електронний pecypc]. - Режим доступу : http://www.m-learning.org/knowledge-centre/whatismlearning.

14. Дубова H. E-Learning - Обучение с приставкой «е» / Н. Дубова // Открытые системы. - 2004. - № 11. - Режим доступу до журн. : http://www.osp.ru/os/2004/11/184806.

15. Developing a mobile learning strategy [Електронний ресурс]. - Режим доступу : http://www.bcs.org/content/conWebDoc/43280.

16. 6 Questions That Will Help Revamp Your Mobile Learning Strategies [Електронний ресурс]. - Режим доступу : http://www.k12mobilelearning.com/2010/12/6questions-to-help-revamp-your-mobile-learning-strategies.

17. Models of mobile learning [Електронний ресурс]. - Режим доступу : http://www.mobl21.com/blog/14/models-of-mobile-learning.

\section{МОБИЛЬНОЕ ОБУЧЕНИЕ: СУЩНОСТЬ И МОДЕЛИ ВНЕДРЕНИЯ В УЧЕБНЫЙ ПРОЦЕСС ВЫСШИХ УЧЕБНЫХ ЗАВЕДЕНИЙ МВД УКРАИНЫ}

Бугайчук Константин Леонидович, кандидат юридических наук, доцент, ведущий научный сотрудник научно-исследовательской лаборатории проблем профилактики правонарушений и взаимодействия с населением, Харьковский национальный университет внутренних дел, г. Харьков, е-mail: klbugaychuk@gmail.com

\section{Аннотация}

Современные тенденции создания и расширения функциональности портативных электронных устройств заставляют мировое сообщество задумываться об их использовании с образовательной целью. Последние годы ученые все чаще говорят о возникновении обучения с помощью мобильных устройств или мобильном обучении. Автором определена сущность мобильного обучения, его соотношение с дистанционным и электронным обучением, а также определены его преимущества и недостатки. На основании особенностей мобильных устройств, сформулированы правила разработки информационных ресурсов для мобильного обучения. Предложены модели внедрения мобильного обучения в учебный процесс высших учебных заведений МВД Украины. 
Ключевые слова: дистанционное обучение, мобильное обучение, МВД Украины.

\section{MOBILE LEARNING: ESSENCE AND MODELS OF INTRODUCTION IN EDUCATIONAL PROCESS OF HIGHER EDUCATIONAL ESTABLISHMENTS MIA OF UKRAINE}

Konstyantyn L. Bugaychuk, PhD (jurisprudence), docent, senior researcher of Research laboratory on crime prevention and interaction with the population, Kharkov National University of Internal Affairs, Kharkov, e-mail: klbugaychuk@gmail.com

\section{Resume}

Current trends to create and expand the functionality of portable electronic devices make the international community to reflect on their use for educational purposes. In recent years, scientists are increasingly talking about the emergence of learning through mobile devices or mobile learning. The author defined the essence of mobile learning, its correlation with distance learning and e-learning, and outlines its advantages and disadvantages. Based on the characteristics of mobile devices, set out rules for the development of information resources for mobile learning. The models of implementation of mobile learning in the educational process of higher educational establishments MIA of Ukraine are offered.

Keywords: distance learning, mobile learning, MIA of Ukraine. 